\section{RESPONSE OF CENTRAL EUROPEAN CIVIL SECURITY SYSTEMS TO THE ECONOMIC CRISIS}

\section{Věra - Karin Brázová1}

Charles University in Prague

Abstract: The public sector across Europe and elsewhere was affected by the economic crisis which fully unfolded in 2008. Considerable attention has been paid in the literature to the impacts of related budgetary cuts on social welfare, while some other areas remain largely under-researched. One of such areas is the so-called civil security, where no such endeavour has been attempted so far. In order to fill this gap, the paper examines the civil security systems of Central European countries (Czech Republic, Slovakia, Poland and Hungary), employing a qualitative comparative analysis. Taking on the systems perspective, the article inquires how the stress posed by the economic crisis affected the civil security systems - their structure and financing. The paper builds on the findings from a 7th FP project, "ANVIL", within which data on civil protection and disaster manage ment systems were collected.

Keywords: economic crisis, security system, civil security, disaster management, Central Europe, Visegrad Group, systems approach

VĚRA - KARIN BRÁZOVÁ - Charles University in Prague, Faculty of Social Sciences • v.k.brazova@gmail.com

Central European Journal of Public Policy Vol. 9 - № 2 - December 2015 - pp 142-163 ISSN $1802-4866$

○ 2015 Věra - Karin Brázovă

Licensed under Creative Commons Attribution 3.0

1 The paper was supported by grant "Adaptace bezpečnostního systému ČR na měníci se ekonom ickou, sociální, demografickou a geopolitickou realitu" (VG 20132015112).

\section{INTRODUCTION}

The public sector across Europe and elsewhere was affected by the economic crisis which fully unfolded in 2008. Considerable attention has been paid by the academic literature to the effects of related budgetary cuts in the realm of social welfare (see, e.g., Vis et al. 2011, O’Reilly et al. 2011, Starke et al. 2012). It can be argued, however, that social policies are only one (albeit important) part of public spending. The aim of this article is to discuss the impact of the economic crisis upon another public good so far neglected in the analyses - namely the so-called civil security. It is a common feature of security that, typically, not much attention is paid to this domain until an immediate threat appears (see, e.g., Birkland 1998). In the absence of an imminent threat, it tends to be understood as a low-cost activity and ascribed lower priority compared to other policy domains (Penning-Rowsell, Wilson 2006; Choi 2005), thus it is also potentially more susceptible to budgetary cuts. While the consequences of austerity measures in the field of military security in Central Europe have been researched (Stř́tecký 2012), no similar endeavour has been attempted so far in the field of civil security. This article seeks to fill this gap.

To do so, the paper examines the civil security systems (CSSs) designed to deal with crises (e.g., technological or natural disasters). The economic crisis is different as it impacts directly on the CSSs and puts them under stress - a different one than they are designed to deal with. The research question then is: How did the stress posed by the economic crisis affect the CSSs?

In order to address the research question, the paper employs a qualitative comparative analysis of four Central European countries as represented by the Visegrad Group (V4). This is in line with Drabek (1970) who calls for analyzing systems' response to severe disruption (ibid, 334) and suggests studying several units (as opposed to one) exposed to such disruption. The V4 seems to represent a reasonably good ground for comparison: Firstly, the CSSs of these countries exhibit similar development patterns both in form and time. They developed in response to the same stimuli, such as the political change in 1989, further integration into the European Union, or (from the perspective of crisis response) floods which are the prominent natural disaster in the region and have led to the adaptation of the CSSs in the past (see Brazova et al. 2015). Moreover, although the structure of these CSSs and the underlying values are not identical, they differ from other EU countries such as Sweden, Great Britain or Italy (Bossong, Hegemann 2013). Secondly, the V4 countries do differ substantially with respect to the economic crisis - while Hungary had to turn to the International Monetary Fund (IMF), Poland was one of the very few European countries not turning into recession. Due to the aforementioned simi- 
larities in the countries' CSSs development, the impacts of the economic crisis could be compared.

The paper builds on the data collected within the EU 7thFramework Programme project entitled ANVIL ("Analysis of Civil Security Systems in Europe") on civil protection and disaster management systems in 22 European countries, including all the V4 countries. The study is based on analysis of documents, of ficial reports as well as on information obtained from practitioners during various workshops between 2012 and 2013. In the first section of the paper, the topic is framed in a systemic approach, and the scope of the economic crisis in the V4 countries is overviewed. In the next two parts, recent changes in the CSSs' structure and in the related spending are presented, respectively. The findings are discussed in the concluding section.

\section{THEORETICAL BACKGROUND}

The paper deliberately focuses on the so-called CSSs, which can be understood as tools of crisis management with civil protection lying at their core (Udeanu 2012). Unlike the notions of crisis or emergency management, the notion of a CSS enables us to better delimitate the object of study and allows for a systemic perspective. As it will be argued further, a systems approach seems to be well suited for the analysis of the impacts of the economic crisis in the civil security realm. It can be maintained that civil security forms a specific and distinct sub-part of the entire security system of a country ${ }^{2}$, despite a certain level of interrelatedness with other sub-systems. CSSs can thus be distinguished from other security-related subsystems, such as the military or law enforcement (Shalamanov et al. 2005). As such, civil security refers especially to extraordinary events, including vulnerability reduction, response and recovery measures (Dory 2003)

The idea of security systems designed according to "first-order cybernetics" was quite prominent in security studies of the 1950s and 1960s. After be ing sidelined for some time, systems theories have exhibited a large revival over the last decade. Unlike the first generation of systems thinking, focusing predominantly on the structure and functions of the system, the second gen eration builds mostly on complexity studies. In this way, the qualities and capabilities of a system (such as resilience or adaptability) get more into the forefront (Walker Cooper 2011; Collier, Lakoff 2015; see also Perrow 1984; Alexander 2013). In parallel, there have been attempts to employ phenomenology

2 All V4 countries invoke a systems perspective in their national security strategies. and the interpretive paradigm in the study of systems (Zexian, Xuhui, 2010), yet for the purpose of this paper, it is more convenient to follow the more traditional (see, e.g., Jervis 1997) functionalist approach - understanding the system under study as objectively existing, with a specific structure and a specific goal, ultimately oriented at achieving optimal results (Zexian, Xuhui, 2010 p. 142-144; see also Domański 1998).

Economic crisis is often represented as a critical juncture in policymaking (see Vis et al. 2011, 338-339). In the wake of the financial and especially of the subsequent debt crisis, policymakers all across affluent democracies promised to make substantial cutbacks in public expenditures (Tepe 2012). With an increased accent on efficiency as a core value in the field of public administration (Rutgers, van der Meer 2010), solutions viable in the long run are desirable. At the same time, when confronted with a crisis, governments tend to prefer quick solutions (Peters et al. 2011) such as immediate budgetary cuts. Especially in the absence of any long-term (strategic) vision (Peters 2004, Sorensen, Torfing 2009, Loorbach 2010), this might lead to deterioration of both quality and scope of public goods provision, one which might be hard to recuperate.

These general observations apply to the CSSs as well: According to Collier and Lakoff (2015), disputes about emergency management today revolve around the allocation of resources "in the face of an uncertain future" (ibid, 46). Similarly, Laor et al. (2005) stress a growing demand for accountability, linked with economic principles, in the field of disaster response (ibid, 34). Taken more generally, resilience of a system depends on its resources (Lizarralde et al. 2015) and on its efficient functioning when the resources are limited (Senge 2007). Thus, it is important to ask about cuts in the spending on civil security and about related efficiency measures.

While crises (including the economic one) are commonly seen as negative events, causing harmful disruptions or perturbations threatening the functionality or even the very survival of the affected system (Forgues, Roux-Dufort 1998; 5), this does not always have to be so. A crisis might also have positive revealing properties (Shrivastava 1993). For example, it could bring about changes beneficial for the system (e.g., a re-organization increasing the system's robustness) and thus also contribute to its resilience (Forgues, Roux-Dufort 1998) or even antifragility ${ }^{3}$ (Taleb 2012). The economic crisis as well put the CSSs under stress, yet potentially also lead to their adaptation and evolution.

3 The word was introduced by Taleb (2012) and denotes the opposite to fragility, i.e. the quality of a subject actually benefitting from shocks (ibid, pp. 4-5). 
Forgues and Roux-Dufort (1998) underline the importance of a relatively novel concept of learning in crisis management, leading to transformation (ibid, 17). Stephens et al. (2013) also stress learning (in particular the concept of a learning organization) and link it with the systemic approach. Similarly, Shrivastava (1993) and Lizarralde et al. (2015) point to the restructuring (or reorganization) of systems induced by a crisis. Following these observations, we may expect the economic crisis to lead to (some) restructuring in the CSSs.

Such restructuring may take on two essential forms: 1) a greater (de)centralization at the vertical level; and 2) privatization at the horizontal level. The evidence from other policy realms suggests that the economic crisis triggered substantial changes "in the set of relationships of policy actors at different levels of governance" (Randma-Liiv 2014, 7). In this context, especially the tendencies to both centralization and decentralization reportedly emerged as a result of the economic crisis (Peters et al. 2011, 17-18). The literature on security governance (Krahmann 2003) then points to a growing involvement of differen stakeholders (both from the for-profit and the civic sectors) in security provision. Especially the increasing budgetary pressures were reported to encourage privatization and outsourcing of some security functions of the state (ibid; Brudney, Gazley 2009).

Building on the considerations above, the paper adapts the work of Chroust et al. (2011) on systemic responses to disasters as its analytical framework. The authors speak of "compensating actions" which are needed to bring the system affected by a crisis back to an acceptable state (ibid: 5). For analytical purposes, they distinguish two phases: intervention, which is generally short-term; and restoration, which transforms "the system into a more acceptable state which promises long-term dependability" (ibid: 8). In the latter phase, "efficiency and long-term considerations take priority" (ibid). Al the systemic responses identified in the literature above (austerity meas ures, efficiency measures and re-structuring) can be thought of as compensating actions. While the immediate austerity measures can be categorized as the short-term intervention, the two remaining ones would fall under restoration The analysis below will seek to identify (potential) changes in the CSSs along these lines.

\section{ECONOMIC CRISIS IN THE V4 COUNTRIES}

The V4 countries were affected differently by the economic crisis. Poland was the only one not experiencing a GDP decline in 2009. This decline repeated itself, yet on a smaller scale, in the Czech Republic and in Hungary again in 2012.
What happened to be a recession in other countries was only a slowdown of the economy in the Polish case (see Figure 1). ${ }^{4}$

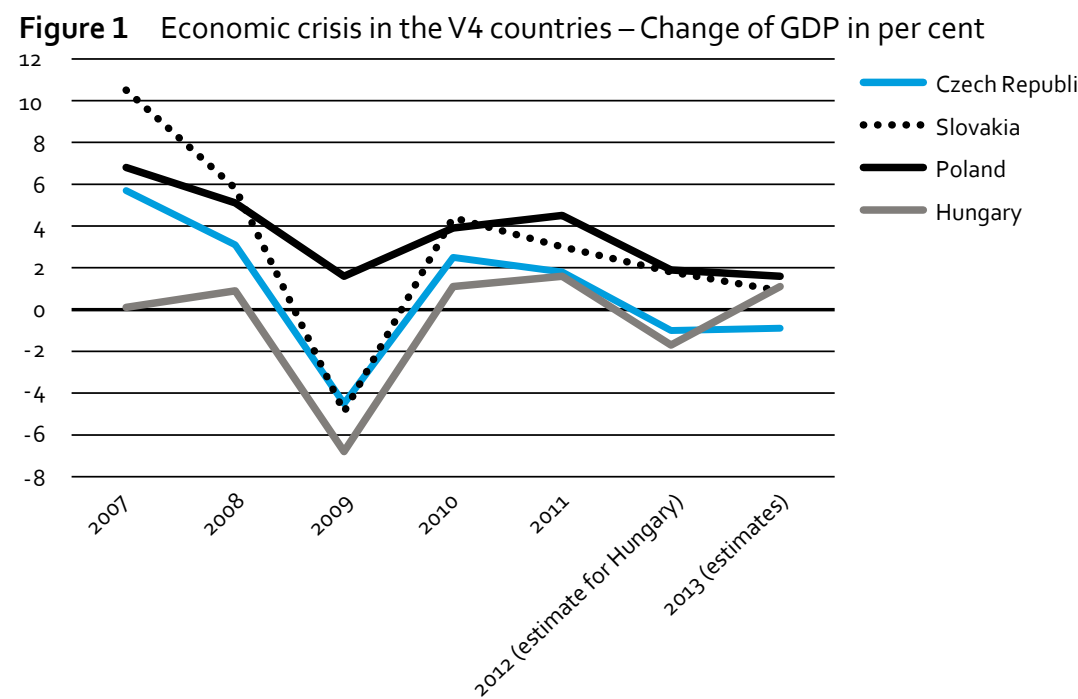

Source: Author, based on the International Monetary Fund's World Economic Outlook Database, April 2014

Hand-in-hand with the economic downturn went also a debt crisis in many European countries. In the case of Hungary, this was already felt well before the credit crunch as the governmental debt had been growing ${ }^{5}$ due to a persistent employment and demographic crisis. In 2008, Hungary had to turn to the IMF and to employ severe austerity measures. The aim of budget deficit reduction lead to substantial cuts in public services (Tóth et al. 2012,138-144).

While the indebtedness exceeded $80 \%$ of GDP in Hungary ${ }^{6}$, it was considerably smaller in the other three countries ${ }^{7}$. However, there has been a rising tendency in this respect. The gross governmental debt exceeded 50\% of GDP in Poland in 2009 and in Slovakia in 2012. In the latter case, although few expressed fundamental concerns about the sustainability of the country's pub-

4 On the other hand, it has to be noted that Poland had the lowest level of GDP per capita of the V4 countries (12,709 USD in 2012 - current prices), and only recently levelled up with Hungary (12,544 USD in 2012 - current prices) which was the hardest hit by the crisis.

5 General government gross debt reaching 73\% of GDP in Hungary in 2008.

$682.1 \%$ in 2010.

$745.7 \%$ in the Czech Republic; $52.4 \%$ in Slovakia; 55.6\% in Poland in 2010 
lic finances, there have been significant cuts in public spending (Leschke et al 2012, 267).

\section{RE-STRUCTURING IN THE CIVIL SECURITY SYSTEMS?}

This section addresses the structure of the CSSs and identifies changes in the 1) competencies, especially alongside the vertical axis indicating (de)centralization; 2) involvement of the civic sector; and 3) involvement of the for-profit sector. The findings are summarized in Table 1.

\section{Structure of the CSSs and its changes}

In the Czech Republic, the CSS was fully created in the year 2000 with the adoption of crisis-related legislation ${ }^{8}$. The leading policy maker is the Ministry of the Interior and its General Directorate of the Fire Rescue Service. The responsibility for implementation and for dealing with crises rests upon the regions. These are self-governing units performing also state administration tasks on behalf of central government, including security-related issues, within the so-called joint model of public administration. Operationally, civil security is ensured through the Integrated Rescue System (IRS) - an operating platform for crisis response comprising three main agencies (fire service, emergency medical services and the Police) and a number of secondary agencies which do not assume a leading role but provide assistance during a crisis. The most important of these are voluntary firefighters and also the military (Act on the IRS No. 239/2000 Coll.). Since 2000, no major reform has taken place which would significantly affect the design of the Czech CSS (Brazova et al. 2015).

In Slovakia, the current CSS was legislated in 2002. The role of the state administration in this field is crucial (Buzalka et. al. 2011; 9-12). Within the socalled parallel model of public administration, the responsibility for civil security rests mostly with central government institutions and with the Min istry of the Interior. The competencies of regional governments in the field of civil protection were broadened by a reform in 2011, enabling these to establish crisis funds so as to cover their expenses related to extraordinary events such as local floods or heavy snowfall (Brazova et al. 2014). Operationally, similarly as in the Czech Republic, the so-called Integrated Rescue System (IRS) is in place. Its composition is, however, not identical: the Ministry of the Inte-

8 Including the Act on the Integrated Rescue System, the Crisis Act, the Act on Economic Measures for the States of Crisis and the Act on Public Health Protection. rior has the leading and coordinating role. There are three categories of rescue bodies: 1) Basic Rescue Services (fire service, emergency medical services, Civil protection control chemical laboratories, Mountain Rescue Service, and Mine Rescue Service); 2) Other Rescue Services (e.g., the military, municipal fire brigades, Civil Protection Units, Slovak Red Cross, etc.) and 3) the Police (Act No.192/2002 Coll.). In 2011, a reform of the IRS was announced to be completed in 2015 with the aim to increase the system's functional effectiveness (Ministry of the Interior of Slovakia 2011). Disputes, however, have emerged concerning the leading role - whether this should remain in hands of central government or rather be entrusted to operational bodies.

In Poland, at the national level, civil security rests with the Ministry of the Interior and its National Headquarters of the State Fire Service, whose Commander-in-Chief is also the Chief of National Civil Defence. At the lower levels, the regional governors play a key role, coordinating prevention activities and assisting lower levels of administration. Operationally, the State Fire Service is the main part of the so-called National Fire-Fighting and Rescue System established in 1995, which integrates also other bodies such as voluntary firefighters, emergency medical services, etc. (Fire Protection Act of 1991, Art. 2.4). The responsibility for civil security was entrusted to the Ministry of the Interior by an administration reform in 1997. The largely mismanaged floods of the same year then triggered further changes. Laws on crisis management and civil security started to be drafted in 2001 and were finalized in 2007 (Brazova et al. 2015, 10-11). Although e.g., the abolishment of the (rather ineffective) civil defence system has been debated, there are currently no major structural changes in the field of civil security either underway or considered in Poland (Matczak, Abgarowicz 2013).

In Hungary, disaster management rests especially at the national level. Regional and local levels are represented by County Disaster Management Directorates and Disaster Management Branch Offices, respectively (comprising of local authorities, disaster management authorities, the military, police, health care and water management authorities). Civil protection was codified in 1996 and became a part of a disaster management system in 1999, after the adoption of the Disaster Management Act (Takacs, Matczak 2013). The system changed significantly in 2000 when disaster management authorities were established (combining civil protection and state fire-fighting organizations) and then later mostly due to the harmonization with EU law (see Brazova et al. 2015). Recently, the civil security system underwent further changes towards more centralization and a greater role played by the Ministry of the Interior. After 2012, all civil protection, most fire-fighting tasks as well as flood protection became the responsibility of the Ministry of the Interior. A strong role is now played by the National 
Directorate General for Disaster Management (NDGDM) under the Ministry of the Interior, which has a supervising position over all cooperating institutions involved in civil security (Takacs, Matczak 2013). Overall, these changes focused on both the efficiency and effectiveness of performance - the latter especially in response to the Ajka red mud sludge disaster of 2010 (Brazova et al. 2015).

\section{Civic sector involvement}

In the Czech Republic, the involvement of the civic sector is characterized especially by voluntary firefighter units which are typically established by municipalities and financed through grants of the Ministry of the Interior and by the Regions. With respect to the economic crisis, the administration started to discuss the potential to engage these more in the provision of civil security to make up for the budgetary cuts, as the voluntary firefighters have a long tradition in the country and already constitute a part of the national IRS, being also assigned to enterprises such as chemical plants (Association of Voluntary Firefighters, undated). Another important civic sector organization is the Red Cross, focusing especially on first aid, humanitarian aid and disaster relief. Although there are also other NGOs at least partially involved in civil security (specializing on in-kind donations and voluntary help), these are relatively less important compared with the two previous ones.

In Slovakia, voluntary firefighters are an important part of the civic sector: Although these are often the first to respond to a crisis (especially in small municipalities), their underfunded equipment is not fully sufficient to substitute for professional fire service. Most of the finances for these organizations come from local governments and from sponsors (Rusňáková 2011). In November 2010, an official agreement between the Ministry of the Interior and the Slovak Red Cross (SRC) was signed. The SRC is now a part of the IRS and a member to the Central Crisis Staff and crisis staffs at the local level (Návrh Koncepcie, un dated). There are also other NGOs involved in civil security, yet these are significantly smaller and have a less privileged position compared to the SRC.

In Poland, the civic sector in civil security is represented especially by the voluntary firefighters which form the largest part of the voluntary sector in Poland and cooperate closely with the State Fire Service. Other civic organizations such as voluntary rescue services are comparatively smaller. The main source of finance for the activities and equipment of these organizations comes from government authorities. At the regional and local levels, also other NGOs are involved, such as the Caritas or the Red Cross. Over the last years, also spontaneous engagement of citizens helping during an emergency has been growing (Matczak, Abgarowicz 2013).
In Hungary, the civic sector has been growing over the last fifteen years, including the field of civil security. The involvement of NGOs is stipulated in disaster prevention plans and there is a formal partnership between these and the NDGDM or the regional directorates. The most important organizations are the Red Cross (as the largest NGO in Hungary), charity organizations (e.g., the Hungarian Maltese Charity or the Caritas) and the voluntary firefighters, with a long tradition in the country. Under the reforms of 2012, however, municipa firefighters were subjected to state supervision and the organizations of voluntary firefighters were limited in their activity. They are now obliged to pay the road tax and, unlike in the past, cannot receive old equipment from the state firefighters. At the same time, engagement of the Red Cross has been codified through a formal cooperation agreement (Takacs, Matczak 2013).

\section{For-profit sector involvement}

In the Czech Republic, there are not many private bodies involved in civil security provision as the absolute majority are public ones. An exception are for-profit emergency medical services (typically smaller than the emergency medical services established by regional authorities). A majority of the Air Ambulance (an integral part of the IRS) are also operated by private bodies, although two stations remain operated by the Police and by the military (DSA undated). Despite the relatively small involvement of for-profit organizations in the provision of civil security, privatization has not been considered.

In Slovakia, although the state plays a dominant role in the provision of civil security, there are some private bodies taking part as well. This holds especially for the field of health provision: In 2004, the Government privatized the emergency medical services ${ }^{9}$. While the aim was to decentralize the management and to introduce market principles, economic considerations were the main driver (Dragula 2007). Also the implementation of the EU SEVESO Directive opened up the field for private companies. In Slovakia, it is especially the Falck Fire Services which has been providing fire-fighting brigades for large industrial enterprises since 2007.

In Poland, the role of the public administration is crucial. Private companies are contracted to secure logistics or to provide sanitary equipment and temporary shelters in case of emergency. Also the emergency medical services (as a part of the state health system until 1990) are contracted out (Matczak, Abgarowicz 2013).

9 Although aiming at general health care, this had an implication for the CSS as well, as emergency medical services constitute a part of the basic rescue services of the Slovak IRS. 
In Hungary, for-profit organizations in civil security can be found especially in the field of training and logistics. Apart from this, agreements are also signed with companies providing rescue or other special machinery for firefighting and road accidents. Pending the coming into force of the new laws, more of such agreements are expected to be signed in the near future (Takacs, Matczak 2013).

Table 1 Re-structuring in the CSSs since 2009

\begin{tabular}{llll}
\hline Country & $\begin{array}{l}\text { Changes } \\
\text { in competences }\end{array}$ & $\begin{array}{l}\text { Changes in the } \\
\text { civic sector's formal } \\
\text { involvement }\end{array}$ & $\begin{array}{l}\text { Changes in the } \\
\text { for-profit sector's } \\
\text { involvement }\end{array}$ \\
\hline Czech Republic & No & No & No \\
\hline Slovakia & $\begin{array}{l}\text { Yes - crisis funds of } \\
\text { regional governments }\end{array}$ & Yes (Red Cross) & No \\
\hline Poland & No & No & No \\
\hline Hungary & $\begin{array}{l}\text { Yes (centralization) - } \\
\text { concerns both function } \\
\text { and finances }\end{array}$ & $\begin{array}{l}\text { Yes (Red Cross \& } \\
\text { limiting the voluntary } \\
\text { firefighters) }\end{array}$ & Yes (rather minor) \\
\hline
\end{tabular}

Source: Author's compilation based on the previous analysis

The economic crisis represented a challenge but - with some exceptions in the case of Hungary - was not a trigger of any major re-structuring in the coun tries' CSSs. While we would expect Poland to be an outlier (as the only country not hit by the crisis), this does not find any support in the data. In Hungary, it was rather the long-term financial malaise which resulted in the structural change of the CSS and in the centralization of civil security functions. Here, however, the economic crisis was rather a contributing factor and as such did not trigger the CSS changes. When combined with the large floods and the Ajka disaster in 2010, the underfunding reached the operational limits of the system. The following reforms were meant to increase both effectiveness (e.g., through greater involvement and responsibilities of private companies so as not to repeat the Ajka disaster) and efficiency (through centralization of civil security functions and procurement ${ }^{10}$ ).

Outsourcing on a larger scale was not considered in any of these countries. Although there is some involvement of the private (for-profit) sector, especially in the emergency medical services in Poland and in Slovakia, the decisions to

10 See parts 5.2 and 5.3 below. outsource this part of civil security took place well before the economic crisis. Again, only in Hungary did several (although not large-scale) changes take place in this respect, with the privatization of some support and logistics functions as a result of the crisis.

Similarly, none of the CSSs started to rely significantly more on the civic sector as a result of the crisis. There has been some increase in spontaneous volunteering observed in Poland and in the number of civil security NGOs in Hungary, yet these developments do not seem to be (directly) related to the economic crisis. Rather, they appear to be an expression of social capital (Putnam 1995) of a growingly active civil society. The Red Cross recently started to play an important role in Slovakia and Hungary, being newly recognized as the government's official partner in the field of civil security. Nevertheless, no direct link to the economic crisis has been established here.

What deserves attention, however, are the structural changes in civic sector engagement, namely concerning the voluntary firefighters. These have a long tradition in all four countries. In the aftermath of the economic crisis, a diverging tendency can be observed: in Poland and in the Czech Republic, these bodies are firmly integrated into the official platforms for dealing with emergencies (the National Fire-Fighting and Rescue System and the Integrated Rescue System, respectively), enjoying relatively significant co-financing from the state budget. In the Czech case, the potential for a greater exploitation of this form of volunteering started to be officially discussed in the wake of the economic crisis. In Slovakia and Hungary, on the other hand, the voluntary firefighters are more dependent on other forms of financing (municipal, sponsoring) and are considered comparatively less important. The economic crisis did not improve their position but rather worsened it, especially in the Hungarian case.

\section{SPENDING ON CIVIL SECURITY}

The impact of the crisis upon the CSSs can only be estimated. Firstly, there are no commonly recognized indicators of performance in disaster management. Secondly, the data lack comparability and are often inaccessible (Jachs 2014). The following parts are looking at the spending on civil security in the V4 countries and at the efficiency measures. The results are summarized in Table 2 below. 


\section{A note on the clarity of spending}

The ANVIL reports suggest that European governments do not have a clear overview of their spending on civil security and crisis management. This is of ten the result of multi-level financing, with regional and/or local governments playing an important part in the funding scheme. In the V4 countries, a somewhat clearer picture exists as civil security is mostly in the hands of the state authorities and of ministries of the interior. However, even there it is difficult to draw a complete picture.

In the Czech Republic, there is a clear overview at the central level - according to the itemized budgetary chapter on security - but no comprehensive information exists for the regional and local levels. There are often multisource financing frameworks -e.g., the fire service gets financial contributions also from the regions. The regional budgets are a source for financing the emergency medical services and for co-financing the voluntary firefighters.

In Slovakia, the state budget - or, more specifically, the budget of the Ministry of the Interior - is crucial. Most of the civil security provision is financed from this source.

In Poland, expenditures on civil security are institutionally scattered among different parts of the administration and included in different chapters of the state budget, which makes them difficult to assess. Different levels, too are involved in the financing of the fire service and crisis management. Even for the government, it is rather hard to estimate the actual expenses. Recently, adherence to proper classification of expenditures on crisis management was recommended by the Supreme Audit Office in order to increase the transparency and efficiency of the civil security system (Matczak, Abgarowicz 2013).

In Hungary, despite a high level of centralization in the field of civil security, disaster-related expenses are scattered, partially resting also on regional and local governments. Within the state administration, too, the expenses for civil security are born by different authorities. Similarly as in Poland, in 2010 the General Accountancy Office recommended to increase transparency and efficiency by establishing a common budget for all disaster management-related costs (Takacs, Matczak 2013)

\section{Austerity measures}

In the Czech Republic, the largest cuts over the last couple of years occurred in 2011. The state budget section on fire protection and the IRS was reduced by some 1.4 billion Czech Crowns (CZK) - from 8.4 billion CZK (approx. 336 mil- lion EUR ${ }^{11}$ ) in 2010 to 7 billion CZK (280 million EUR) in 2011. In 2012, the decrease continued, yet on a substantially smaller scale, with 6.8 billion CZK (272 million EUR), i.e. $0.6 \%$ of the total annual budgetary expenditure, being budgeted for fire protection and the IRS (Ministry of Finance 2012). In contrast, the expenditures on civil preparedness for crisis situations (another section in the budget) remained relatively constant over the last years. There was a decrease of 0.2 billion CZK ( 8 million EUR) in 2011 compared with 2010. The spending in 2012, however, increased again by 0.2 billion CZK to a total amount of 2.3 billion CZK ( 92 million EUR) or $0.2 \%$ of the total budgetary expenditures. It has to be noted, too, that most of the resources in this category were spent on the State Material Reserves, including oil reserves and emergency supplies (ibid).

In Slovakia, the state expenses on security and public order typically represent some $8.5 \%$ of the overall budget. Apart from fire protection, also the work of the police is included here. From the budget of the Ministry of the Interior the second largest amount (after the Police) typically goes to rescue services (99.5 million EUR in 2011). Between 2010 and 2011, the expenses on security and public order were reduced by 62.7 million EUR. After an increase from 1.13 billion EUR in 2009 to 1.33 billion EUR in 2010, the budget decreased to 1.27 billion EUR in 2011. For the year 2012, an even smaller amount was budgeted (1.25 billion EUR), yet this was later revised and raised to 1.32 billion EUR. According to the annual government finance data, then, the real expenses in this budgetary chapter reached 1.34 billion EUR - a level as high as in 2010 (Ministry of Finance 2013; Ministry of Finance 2012). Although the concept of civil defence was abolished in 1994, civil protection activities still remain in the budgetary section for defence. Here, a trend of reduction can be observed. After the expenses for civil protection were 8.4 million EUR in 2009 and 10 million in 2010, there was a significant decrease to 2.9 million EUR in 2011. In 2012, the expenses for civil protection somewhat increased to 3.16 million EUR, yet they did not reach the level of 2010 (ibid).

In Poland, the spending on public security and fire protection was approximately 3.078 billion EUR, making up $4.3 \%$ of the overall state budget. A large part of the figure, however, is budgeted for the police. The size of the budget of the headquarters of the State Fire Service is some 30 million EUR and the sum allocated for crisis management from the central level makes up 1.5 million EUR. Financing from the central level also includes the voluntary firefighters with 5.5 million EUR and the mountain and water rescue services with 3 million EUR. The budget for civil defence was on average 7.3 million EUR in the years 2009-2013. According to an expert assessment, despite occasional vari-

11 Calculated at a rate of $1 \mathrm{EUR}=25 \mathrm{CZK}$ 
ations, the expenses on civil security did not change in recent years (Matczak, Abgarowicz 2013).

In Hungary, the budget for disaster management was 47.5 billion Hungarian Forints (HUF), i.e. approximately 156.8 million EUR ${ }^{12}$ in 2012, making up $0.34 \%$ of Hungary's total public expenditures. The size of the budget, however, proved not to be sufficient and additional 650 million HUF (2.1 million EUR) were allocated for disaster management (Takacs, Matczak 2013). The salaries of the police, firefighters and soldiers have been frozen for years (Reuters 16. 4. 2011). In 2011, the NDGDM was committed to strict cost saving. The expenditures of this organization were 10.8 billion HUF (approx. 35.5 million EUR). Through an extraordinary government measure, additional 7.1 billion HUF (23.4 million EUR) were granted to the professional firefighters (including the professional municipal firefighters) to reimburse for unpaid overtime. There was also a subsidy of 120 million HUF (0.4 million EUR) available for voluntary firefighters - their education, training and improvement of technical supply (NDGDM 2012, 43-45). The revenues gained from the fire protection fines and contributions of insurance companies - 4.9 billion HUF (16 million EUR) - were spent on firefighting equipment, renovation of fire stations and an upgrade of the public information and alert system. It was also in 2011 when a central equipment supply system was established with the aim to enhance purchasing efficiency (ibid).

The figures on budgetary spending tell only one part of the story. Another issue is that of sufficiency in the financing of civil security. According to the ANVIL data, underfunding in the field of civil security is considered a problem in Hungary, Poland and Slovakia. The lack of finances as one of the key problems for the effectiveness of the civil security system was discussed in the official reports on disasters, especially floods, which occurred in 2010.

\section{Efficiency measures}

In the Czech Republic, general cost-saving measures were introduced, concerning all functional levels. With that aim, especially investments were reduced and financing focused on operational expenses (John 2011). While civil security does not lie in the forefront of the public debate(including the parliamentary one), most of the debate on saving that appeared focused on cost reduction as opposed to discussing efficiency in a broader sense.

In Slovakia, too, significant cuts were made especially in capital expenditures in the field of civil protection. While the budget for operational expenses shrank only by a relatively small proportion, the capital expenditures were re-

12 Calculated at a rate of 1 EUR $=299$ HUF duced from 6.6 million EUR in 2010 to only 0.016 million in 2011. In 2012, the capital expenditures increased, yet not dramatically, reaching 0.6 million EUR (Ministry of Finance 2013; Ministry of Finance 2012). There was an ad-hoc check of efficiency realized by the National Security Council in 2011, but no such procedure has been introduced on a regular basis.

In Poland, the public debate concerning civil security did not focus on efficiency but rather on the aforementioned underfunding. Generally, in the civil security, virtually no efforts aimed at efficiency were made. Although there was some restructuring in the CSS over the last couple of years, this was not driven by any serious financial considerations; effectiveness and political considerations were rather in the forefront. Also the (relatively limited) outsourcing of some of the civil security tasks was not driven by the need to increase the cost effectiveness (Matczak, Abgarowicz 2013).

In Hungary, a direct link was made between underfunding and ineffectiveness. This became apparent during the flood in 2010 when an acute lack of finances endangered the basic functioning of the system. Since 2011, there has been a clearly articulated effort to increase efficiency in disaster management, reaching beyond a simple cost reduction. Annual efficiency reports are now required. The core of the reform in civil security was based on efficiency and financial transparency recommendations - with cost effectiveness being key norm to follow. For this reason, the system became more centralized (see section 4.1.). The outsourcing of civil security training and logistics which occurred over the last years was also done with the aim to increase efficiency (Takacs, Matczak 2013)

Table 2 Austerity, efficiency and spending in the V4 countries

\begin{tabular}{lllll}
\hline Country & $\begin{array}{l}\text { Changes in } \\
\text { spending on civil } \\
\text { security after } \\
2009\end{array}$ & $\begin{array}{l}\text { Under-spending } \\
\text { perceived as } \\
\text { a problem for } \\
\text { effectiveness in } \\
\text { civil security }\end{array}$ & $\begin{array}{l}\text { Civil security } \\
\text { budget overrun }\end{array}$ & $\begin{array}{l}\text { Focus on } \\
\text { efficiency } \\
\text { measures }\end{array}$ \\
\hline Czech Republic & Decrease & No & No & No \\
\hline Slovakia & $\begin{array}{l}\text { Oscillating, } \\
\text { decrease in Civil } \\
\text { Protection }\end{array}$ & Yes & Yes & No \\
\hline Poland & Constant & Yes & NA & No \\
\hline Hungary & $\begin{array}{l}\text { NA, generally } \\
\text { low level }\end{array}$ & Yes & Yes & Yes \\
\hline
\end{tabular}

Source: Author's analysis based on ANVIL data 
Looking at the countries' spending on civil security, the CSSs were indeed af fected by the crisis. Poland (not affected by the economic downturn) was the only case where the spending remained constant. In the Czech Republic and in Slovakia, there was a relatively large reduction in the spending in 2011. In Hungary, too, emphasis was put on strict cost saving in 2011. While in the Slovak case, the real spending recovered again in 2012 (with the exception of civil protection), the decreasing tendency continued in the Czech Republic (yet at a significantly slower pace), somewhat mirroring the second wave of the economic decline. In both cases, the economic crisis and the related austerity measures were the reason behind the budgetary cuts. Moreover, a long-lasting decrease took place in the field of civil protection in Slovakia. At the same time, more financial responsibility was transferred to regional governments in 2011 when they were allowed to establish crisis funds to cover disaster-related expenses.

Although under-funding in the field of civil security is perceived as a problem in three of the V4 countries, it does not seem to be related to the financial crisis. While this challenge was encountered in Poland, it was not reported in the Czech Republic which was hit by the crisis quite considerably. A potential explanation might lie in the different impacts of the economic crisis and of fiscal austerity, as the Czech Republic's debt is the lowest one of the V4 countries. The overrunning of the budget in Slovakia and Hungary, then, seems to be connected with the low level of civil security spending in general and not with the austerity measures in particular.

The economic crisis did not bring about an increased emphasis on efficiency - at least not universally. This was expected for Poland (not affected by the economic downturn). However, also the Czech and Slovak cases fall in line with Poland. The "keyword" in the 2011 budgetary cuts in the Czech Republic and Slovakia was an overall "cost reduction", rather than "efficiency". Currently, only Hungary has introduced a systematic assessment of civil security expen ditures in terms of efficiency. While the Ajka disaster resulted in structural changes to the Hungarian civil security system (Brazova et al. 2015), the particular stress made on efficiency (Takacs, Matczak 2013) has to be seen especially in the light of both the economic and the debt crisis. Of all V4 countries, Hungary was hit the hardest in this respect, which made the implementation of efficiency measures eventually inevitable.

\section{CONCLUSION}

With the exception of Poland, the Central European CSSs were affected by the economic crisis. Among the compensating actions at hand to keep the systems operational, both short-term (intervention) and long-term (restoration) measures were analyzed. In the cases affected by the crisis, there was rapid intervention in the form of austerity measures. Indeed, the dominant response of the Central European countries in the civil security realm seems to be one of budgetary cuts.

While the rapid intervention phase was undoubtedly there, the restoration phase was far less visible and certainly not universal. All the long-term measures considered (i.e. restructuring and efficiency measures) did not exhibit common pattern across the countries affected by the crisis. Concerning the restructuring, there have been no large changes to the structure of the CSSs in the Czech Republic and Slovakia since the economic crisis began in 2008 Despite the drop in the civil security spending in 2011, the crisis was not reflected in any attempts to re-structure neither the Czech nor the Slovak system. In Hungary, the system was reformed and centralized with the economic crisis, although this was a facilitating rather than a triggering factor. None of the CSSs responded by major privatization - be it by involving the civic sector or the for-profit one (although greater involvement of the civic sector started to be considered in the Czech case).

The efficiency measures were not largely applied. With the exception of Hungary, the countries did not consider implementing these and focused on quick solutions in the form of flat-rate cost reduction. Hence, only a deep crisis combined with large indebtedness (the case of Hungary) seems to have brought about changes including the implementation of efficiency measures.

It can be concluded that the economic crisis did not put the CSSs of the V4 countries (with the exception of Hungary) under such considerable stress to undergo any large changes. It can be maintained that the economic crisis generally did not prompt learning in the CSSs towards evolution and adaptation to a more unstable economic environment. Instead, the crisis seems to have been treated as a temporary phenomenon and short-term intervention measures were deemed sufficient. Only in Hungary, the compensating actions extended beyond intervention and comprised restoration measures on a larger scale.

As no single factor ever determines the overall security environment (Tang $2004,15)$, it has to be noted that the economic crisis was not the only stressor to the CSSs. There were, e.g., large floods in 2010 (i.e. concurrently with the economic crisis) affecting all four countries. These two different stressors conflated in time, and therefore, the results have to be interpreted with some caution. While the exploratory analysis presented here provided a comprehensive overview of the changes in the Central European CSSs occurring with the economic crisis, explanatory studies are suggested for further research, following the rationales behind the changes (or the lack of them). 


\section{REFERENCES}

Act No. 129/2002 Coll. On Integrated Rescue Service of the Slovak Republic Act No. 239/2000 Coll. On Integrated Rescue System of the Czech Republic

Alexander, D. E. (2013). Resilience and disaster risk reduction: an etymological journey. Natural Hazards and Earth System Science, 13(11), 2707-2716.

Birkland, T. A. (1998). Focusing Events, Mobilization, and Agenda Setting.Journal of Public Policy, 18(1), 53-74.

Bossong, R., \& Hegemann, H. (2013). Synthesis report on comparison of civil security systems. Retrived from ANVIL website: http://anvil-project.net/wp-content/ uploads/2013/12/Deliverable_4.1.pdf (Accessed 1. 5. 2015)

Brazova, V. K., Matczak, P., \& Takacs, V. (2015). Evolution of civil security systems: the case of three Central European countries. Journal of Risk Research, 18(5-6), 789-806.

Brazova, V. K., Matczak, P., \& Grodzki, R. (2014). Effectiveness of the Governance Framework in Dealing with Disasters: Czech, Polish and Slovak perspective. In Nađ, I. (Ed.), Crisis Management Days: Book of Papers (pp. 363-380). Velika Gorica: University of Applied Sciences.

Brudney, J. L., \& Gazley, B. (2009). Planning to be Prepared: An Empirical Examination of the Role of Voluntary Organizations in County government Emergency Planning Public Performance, 32(3), 372-399.

Buzalka, J., Keleman, M. \& Blažek, V. (2011). Štúdia vybraných aspektov ochrany obyvatelstva. Košická bezpečnostní revue, 1(2), 3-26.

Buzan, B. (1997). Rethinking Security after the Cold War. Cooperation and Conflict, 32(1) $5-28$

Choi, S. O. (2005). Relative efficiency of fire and emergency services in Florida: an application and test of Data Envelopment Analysis. Int. J. Emergency Management, 2(3), 218-230.

Chroust, G., Sturm, N., Roth, M., \& Ziehesberger, P. (2011, September). Regional disasters and systemic reactions. Proceedings of the 55th Annual Meeting of the ISSS-2011, Hull, 55(1). University of Hull Business School.

Collier, S., J., \& Lakoff, A. (2015). Vital Systems Security: Reflexive Biopolitics and the Government of Emergency. Theory, Culture and Society, 32(2), 19-51.

Domański, R. (1998). Zasady geografii spoteczno-ekonomicznej, Warszawa - Poznań: PWN.

Dory, A. J. (2003). American civil security: The U.S. public and homeland security. The Washington Quarterly, 27(1), s. 37-52.

Drabek, T. E. (1970). Methodology of Studying Disasters. American Behavioral Scientist, 13(3), 331-343.

Dragula, M. (2007). Reforma zdravotnictva na Slovensku. In Conference of the Czech Medical Chamber. Retrived from: http://www.praktikcz.eu/Graphics/dragula_04.pdf (accessed 20. 6. 2014)

DSA (undated). Střediska LZS. Retrived from: http://www.dsa.cz/cz/letecka-zachrannasluzba/mapa-stredisek-Izs (accessed 15. 4. 2013)

Forgues, B., \& Roux-Dufort, C. (1998). Crises: Events or processes. Hazards and Sustainability: Contemporary Issues in Risk Management, (p.18). Retrived from: http:// www.researchgate.net/profile/Bernard_Forgues/publication/254276369_CRISES_
EVENTS_OR_PROCESSES/links/0a85e53bea59c70bd6000000.pdf (accessed 15. 5. 2015)

Jachs, S. (2014). Can we measure the performance of disaster management? In Nađ, I. (Ed.), Crisis Management Days: book of papers (pp. 269-280). Velika Gorica: Veleučilište Velika Gorica.

Jervis, R. (1997). System Effects: Complexity in Political and Social Life. Princeton, New Jersey: Princeton University Press.

John, J. (2011). Úspory ministerstva vnitra, policie ČR a hasičského záchranného sboru. Retrived from://www.mvcr.cz/soubor/zpravodajstvi-dokumenty-uspory-naministerstvu-vnitra-ppt-pdf.aspx (accessed 13. 5. 2013)

Krahmann, E. (2003). Conceptualizing Security Governance. Cooperation and Conflict, 38(5), $5-26$.

Laor, N., Wolmer, L., Friedman, Z., Spirman, S., \& Knobler, H. Y. (2005). Disaster intervention: an integrative systemic perspective for health and social service professionals. NATO SECURITYTHROUGH SCIENCE SERIES E HUMAN AND SOCIETAL DYNAMICS, 4, 33-44.

Leschke, J., Theodoropoulou, S., \& Watt, A. (2012). Hungary's full-blown malaise. In Lehndorff, S. (ed.), A triumph of failed ideas. European models of capitalism in the crisis (pp. 243-282). Brussels: European Trade Union Institute.

Ley, B., Pipek, V., Reuter, C., \& Wiedenhoefer, T. (2012, May).Supporting improvisation work in inter-organizational crisis management. In Proceedings of the SIGCHI Conference on Human Factors in Computing Systems (pp. 1529-1538). ACM.

Lizarralde, G., Valladares, A., Olivera, A., Bornstein, L., Gould, K., \& Barenstein, J. D. (2015) A systems approach to resilience in the built environment: the case of Cuba. Disasters, 39(1), 76-95

Loorbach, D. (2010). Transition Management for Sustainable Development: A Prescriptive, Complexity-BasedGovernance Framework. Governance. 23(1), 161-183.

Matczak, P., \& Abgarowicz, G. (2013). Country Study Poland. Retrived from ANVIL website: http://anvil-project.net/wp-content/uploads/2014/01/Poland_v1.0.pdf (accessed 8. 6. 2014)

Ministry of Finance of the Czech Republic (2012). Tabulková část ke Státnímu rozpočtu ČR na rok 2012. Retrived from: http://www.ospzv-aso.cz/addons/RHSD93/Tabulkova_ cast_ke_SR_CR.xls (accessed 15. 4. 2013)

Ministry of Finance of the Slovak Republic (2012).Final State Account. Retrived from: http://www. finance.gov.sk/Default.aspx?CatID $=8229$ (accessed 4. 5. 2013)

Ministry of Finance of the Slovak Republic (2013).Final State Account. Online at: http:// www.finance.gov.sk/Default.aspx?CatID $=8940$ (accessed 25. 6. 2014)

Ministry of the Interior of Slovakia (2011).Press release on new conception of the Integrated Rescue System. Retrived from: http://www.minv.sk/?tlacovespravy-4\&sprava=vlada-schvalila-novu-koncepciu-fungovania-integrovanehozachranneho-systemu(accessed 4. 5. 2013)

NDGDM (2012). Disaster Management 2011. Retrived from: http://www. katasztrofavedelem.hu/letoltes/eng/szervezet/annual_book_2011.pdf (accessed29. 6. 2014) 
O'Reilly, J., Lain, D., Sheehan, M., Smale, B., \& Stuart, M. (2011). Managing uncertainty: the crisis, its consequences and the global workforce. Work, Employment \& Society, 25(4), 581-595.

Penning-Rowsell, E., \& Wilson, T. (2006).Gauging the impact of natural hazards: the pattern and cost of emergency response during flood events. Transactions of the Institute of British Geographers, 31(2), 99-115.

Perrow, C. (1999). Normal Accidents: Living with High-Risk technologies. Princeton: Princeton University Press.

Putnam, R. (1995). Bowling alone. Journal of democracy, 6(1), 65-78.

Randma-Liiv, T. (2014). Introduction to the Special Issue: The Impact of the Fiscal Crisis on Public Administration. Administrative Culture, 15(1), 4-9.

Reuters (16. 4. 2011). Hungary police and army unions protest over austerity. Retrived from: http://uk.reuters.com/article/2011/04/16/uk-hungary-demonstrationidUKTRE73F1JL20110416 (accessed 25. 6. 2014)

Rusňáková, J. (July 2011). Dobrovoliných hasičov ubúda. Chýba im podpora štátu. Sme.sk Retrived from: http://prievidza.sme.sk/c/5963815/dobrovolnych-hasicov-ubuda-chybaim-podpora-statu.html (accessed 30. 6. 2014)

Rutgers, M. R., \& van der Meer, H. (2010).The Origins and Restriction of Efficiency in Public Administration Regaining Efficiency as the Core Value of Public Administration. Administration \& Society, 42(7), 755-779.

Senge, P. M. (2007). Pátá disciplína: teorie a praxe učicí se organizace. Prague: Management Press.

Shalamanov, V., Hadjitodorov, S., Tagarev, T., Avramov, S., Stoyanov, V., Geneshky, P., \& Pavlov, N. (2005). Civil Security: Architectural Approach in Emergency Management Transformation. Information \& Security, 17, 75-101.

Shrivastava, P. (1993). Crisis Theory/Practice: Towards a Sustainable Future. Industrial and Environmental Crisis Quarterly, 7, 23-42.

Siegfried, J. (2014). Can we measure the performance of disaster management? In Nađ, I. (Ed.), Crisis Management Days: Book of Papers (pp. 269-280). Velika Gorica: University of Applied Sciences.

Sorensen, E., \& Torfing, J.(2009). Making Governance Networks Effective and Democratic Through Metagovernance. Public Administration. 87(2), 234-258.

SRC (2010). Výročná správa 2010. Retrived from: http://www.redcross.sk/fileadmin/user upload/Vyrocne_spravy/VS_2010.pdf (accessed 1. 6. 2013)

Starke, P., Kaasch, A., \& van Hooren, F. (2012, September). Comparing social policy responses to global economic crises: Constrained partisanship in mature welfare states. In ESPAnet annual conference, Edinburgh (pp. 6-8). Retrived from: http://www. pol.ed.ac.uk/_data/assets/pdf_file/0007/89251/Starke_-_Stream_8.pdf (accessed 30. 9. 2014)

Stephens, A. A., Brian Atwater, J., \& Kannan, V. R. (2013). From tulip bulbs to sub-prime mortgages examining the sub-prime crisis: The case for a systemic approach. The Learning Organization, 20(1), 65-84.

Střítecký, V. (2012). Doing More for Less: V4 Defence Cooperation in a Time of Austerity. The Polish Quarterly of International Affairs, 21(2), 65-82.
Takacs, V., \& Matczak, P. (2013). Country Study Hungary. Retrived from ANVIL website: http://anvil-project.net/wp-content/uploads/2014/01/CBSS_v1.0.pdf (accessed 8. 6. 2014)

Taleb, N. (2012). Antifragile: Things That Gain From Disorder. London: Penguin Books.

Tepe, M. (2012). The public/private sector cleavage revisited: The impact of government employment on political attitudes and behavior in 11 West European countries. Public Administration, 90(1), 230-261.

Tóth, A., Neumann, L, \& Hosszú, H. (2012). Hungary's full-blown malaise. In Lehndorff, S. (Ed.), A triumph of failed ideas European models of capitalism in the crisis (pp. 137-154). Brussels: European Trade Union Institute.

Udeanu, G. (2012). The Relevance of Civil Protection Management Efficiency to Maintain Societal Balance within Uncertainty, Caused by Disasters or Armed Conflicts. Military Art and Science, 2 (66), 128-137.

Association of Voluntary Firefighters (undated). Official information server of the Association of Firefighters of Bohemia, Moravia and Silesia. Retrived from: http:// www.dh.czl (accessed 30. 6. 2014)

Walker, J., \& Cooper, M. (2011). Genealogies of Resilience: From Systems Ecology to the Political Economy of Crisis Adaptation. Security Dialogue, 42(2), 143-160..

Zexian, Y., \& Xuhui, Y. (2010). A revolution in the field of systems thinking-a review of Checkland's system thinking. Systems Research and Behavioral Science, 27(2), 140-155.

\section{DATABASES}

ANVIL - Analysis of the civil security systems in Europe (2014): Database on civil security in 22 European countries. Online. Available from: http://anvil-project.net/downloads/ (accessed 25. 6. 2014)

International Monetary Fund (April 2014): World Economic Outlook Database. Online. Available from: www.imf.org (accessed 25. 6. 2014) 